\title{
ODR Redress System for Consumer Disputes
}

\section{Clarifications, UNCITRAL Works \& EU Regulation on ODR ${ }^{*}$}

\author{
Mirèze Philippe $e^{* *}$
}

\section{Abstract}

Despite the evolution and the experience in the field of ODR, it appears that some aspects remain to be clarified in order to attempt to determine which type of procedure would be best adapted to consumer disputes. What does online arbitration mean and is this ODR? What is the profile of the users making use of ODR? What mechanisms are adapted to business disputes and to consumer disputes? Are procedural issues for disputes resolved through mediation similar to those resolved through arbitration? The article discusses about indispensable clarifications which may have an impact on the choice of procedure: mediation or arbitration. It then raises issues related to the UNCITRAL ODR WG discussions on a redress system for cross-border consumer disputes and questions whether types of disputes and potential mechanisms are not confused. Finally, the European Union which adopted a Regulation on ODR for consumer disputes may have found a solution.

Keywords: consumer redress, B2C v/ B2B, ODR, UNCITRAL, EU Regulation.

Online dispute resolution (hereinafter 'ODR') refers to the settlement of disputes in an electronic environment using information technology. When ODR was booming towards the end of the 1990s, people involved in the field of ODR started meeting once a year since 2000 to discuss various issues related to settlement of disputes in the electronic environment, share experience, report on new developments, suggest best practices and contribute to building this field. ${ }^{1}$ The ODR meetings mainly bring together dispute resolution experts, academics, Internet industry leaders, government officials and members of the judiciary. They will be referred to as 'actors' in this article.

At the 12th annual international congress of the Online Dispute Resolution Forum, in June 2013 in Montreal, the author shared some thoughts about clarifications that are indispensable before proceeding with discussions on instruments for settlement of disputes online. As indicated on the ODR 2013 Montreal web-

* The views expressed are those of the author alone and should not be regarded as representative of or binding upon the ICC, the Court or its Secretariat.

** Special Counsel at the Secretariat of the ICC International Court of Arbitration.

1 For information about the history see E. Katsh, 'ODR: A Look at History', in M.S. Abdel Wahab, E. Katsh \& D. Rainey (Eds.), Online Dispute Resolution: Theory and Practice - A Treatise on Technology and Dispute Resolution, Eleven International Publishing, The Hague, The Netherlands, 2012, p. 21. 
site ${ }^{2}$ the goal of the meetings is to set forth an institutional framework of the future of cross-border ODR systems. It was therefore the perfect setting for raising matters that need to be clarified as they may have an impact on the choice of a procedure as opposed to another - mediation or arbitration.

The subject of consumer redress in e-commerce was also debated since 2000 by several organizations, including the Organization for Economic Co-operation and Development (OECD), the Hague Conference on Private International Law (HCPIL), the International Chamber of Commerce (ICC), the United Nations Commission on International Trade Law (UNCITRAL) and Consumers International. In a report from Consumers International of 11 December 2000, ${ }^{3}$ it was concluded that:

While we are pleased to see so much activity aimed at resolving consumer disputes online, so far none of the services we found met all of the criteria for effective consumer dispute resolution in the global electronic marketplace.

Consumer redress in cross-border e-commerce transactions remains one of the main concerns, as no consensus between the various actors has so far been found about the system to put in place for dealing with low-value, high-volume claims.

Despite the evolution in the field of ODR and the experience gained in the last decade, it appears that some aspects remain to be clarified in order to attempt to determine which type of procedure would be best adapted to consumer disputes.

This article will address in turn necessary clarifications (Section 1), before focusing on the discussions of the UNCITRAL Working Group III on Online Dispute Resolution (hereinafter 'UNCITRAL ODR WG') related to consumer redress, as well as discovering the European Union Regulation on ODR, to examine whether the contributors and various actors are on the same wavelength (Section 2).

\section{Necessary Clarifications: Are We Talking about the Same Animals?}

Following the trend of ODR, dispute resolution practitioners called 'online arbitration' any procedure using a Web-based programme. But what does online arbitration mean, and is this ODR (Section 1.1)? What is the profile of the users making use of ODR (Section 1.2)? What mechanisms are adapted to business disputes and to consumer disputes (Section 1.3)? Are procedural issues for disputes resolved through mediation similar to those resolved through arbitration (Section 1.4)? Are we talking about the same animals? The answers to these questions require defining and distinguishing some aspects.

3 Document no longer available on <www.consumersinternational.org $>$. 


\subsection{First Issue to Clarify: What Is Meant by Online Arbitration?}

Online arbitration or e-arbitration ${ }^{4}$ - as opposed to arbitration procedures using information technology facilities - is normally a procedure exclusively conducted online. This type of procedure is feasible mainly in consumer disputes that do not involve complex issues and in domain names disputes. Arbitration procedures, on the other hand, involving issues and amounts at stake that are different from the straightforward consumer disputes are unlikely to be conducted exclusively online for the time being. Such arbitration procedures are more likely to use information technology facilities for communications between the arbitrators and the parties, as well as the dispute resolution provider if any.

This was the case of the arbitration procedures administered by the ICC International Court of Arbitration under its Rules of Arbitration. The ICC has benefited for several years from an information technology facility called NetCase. ${ }^{5}$ NetCase is a platform offering the parties and the arbitrators the possibility to manage their case online and exchange documents and messages through a secure environment. ${ }^{6}$ Information technology was used, but this was not a procedure conducted exclusively online. Arbitrators and lawyers continued meeting in person, and some documents, such as spreadsheets, were transmitted in hard copies.

Is such a type of arbitration - which is not conducted exclusively online but where information technology is used only as a means of communication - considered an online arbitration? The author is of the opinion that whenever a Webbased programme is utilized, it can be considered an online arbitration.

Can these procedures be called ODR? As long as the programme is Webbased, the terminology ODR may be used. As such, NetCase is ODR, the various platforms used by dispute resolution centres - for example AAA, LCIA, WIPO are ODR, the dispute resolution service offered by Modria ${ }^{7}$ is ODR and the online settlement procedures offered by merchants (e.g. eBay) are ODR.

This approach is also adopted by the UNCITRAL ODR WG, which provides some definitions interesting to highlight, although the work is still in progress, and the latest drafts may be modified. ${ }^{8}$ ODR '[...] means online dispute resolution which is a mechanism for resolving disputes facilitated through the use of electronic communications and other information and communication technology,' and an ODR platform is further defined as being '[...] a system for generating, sending, receiving, storing, exchanging or otherwise processing electronic com-

4 For information about issues at stake in e-arbitration, see M.S. Abdel Wahab, 'ODR and E-arbitration', Abdel Wahab et al., 2012, p. 399.

5 See for the services that NetCase offered articles by the author: 'NetCase: A New ICC Arbitration Facility', ICC Bulletin, Special Supplement on Using Technology to Resolve Business Disputes, No. 667, 2004, p. 53; 'New Upgrades to ICC NetCase', ICC Bulletin, Vol. 19, No. 1, 2008, p. 23; 'NetCase: Keep Going Where Progress Leads You', University of Toledo Law Review, Vol. 38, No. 1, 2007, p. 417.

6 The URL address is <www.iccnetcase.org $>$.

7 For information, visit <www.modria.com $>$.

8 See Report A/CN.9/WG.III/WP.123, Para. 19, <www.uncitral.org/uncitral/commission/work ing_groups/3Online_Dispute_Resolution.html $>$. 
munications used in ODR, and which is designated by the ODR provider in the ODR proceedings.' Therefore, irrespective of the mechanism used and as long as information technology is used, the service offered for settlement of disputes is ODR. Finally, an ODR provider is considered to be '[...] the online dispute resolution provider specified in the dispute resolution clause referring disputes to online dispute resolution under these Rules. An ODR provider is an entity that administers ODR proceedings [...].'

\subsection{Second Determination: What Is the Profile of the Users Making Use of ODR?}

Settling a dispute exclusively online depends on the profile of the parties in dispute. The reason for this important distinction is the fact that the procedure is in general different in a business dispute and in a consumer dispute.

Disputes opposing businesses, called business to business (B2B) disputes, usually involve higher value than business to consumer (B2C) or consumer to consumer ( $\mathrm{C} 2 \mathrm{C}$ ) transactions, and may also involve more complex disputed issues than the straightforward consumer dispute. They are in general settled through classical arbitration procedures, during which information technology facilities may be used for the communications, as explained above. Some typical B2B disputes do, however, settle exclusively online, for instance disputes between insurers. A dispute arising out of a purchase of a product or a service by a business for its own consumption may be considered a consumer dispute and settled exclusively online using a simple process.

Conversely, disputes opposing businesses and consumers are normally smallvalue claims compared with the business disputes, although their value may be important for the consumers. Business disputes and consumer disputes should not be placed on the same level; the latter are considered to be straightforward, low-value claims. Consumers are persons acting for their personal needs, unlike businesses who act for commercial purposes. Thus, consumer disputes must be treated differently.

Having drawn the line between the profiles of businesses and consumers and between what is considered to be a business dispute and a consumer dispute, the next issue that requires clarification is the type of mechanism used for business and consumer disputes.

\subsection{Third Distinction: What Mechanisms Are Adapted to Business Disputes and to Consumer Disputes?}

As highlighted above, consumer disputes and business disputes seem to be treated the same way although the issues at stake are different. It is recommended that straightforward consumer disputes be solved through mediation rather than arbitration. In business disputes, either of both dispute resolution mechanisms may be afforded.

In B2B disputes, resolution of disputes under the auspices of arbitration institutions that have their own set of arbitration rules like the ICC is usually the mechanism used. The dispute resolution clause is normally negotiated between the parties who may choose an institution to which potential disputes may be submitted or who decide to submit any dispute to an ad hoc arbitral tribunal. The 
procedures may last between a few months and a few years, they may be costly, the parties are usually assisted by lawyers and an award is rendered at the end of the procedure. A party may have to enforce the award under the New York Convention on Recognition and Enforcement of Foreign Arbitral Awards in one of the 150 signatory countries.

Consumers do not need such long and complicated procedures. They want to obtain redress when they consider that the product or the service they purchased is not satisfactory, most commonly because it is not in conformity with what they ordered, or for late or failure of delivery. The UNCITRAL ODR WG considered that consumer disputes submitted to state courts are difficult to handle mainly because of the low-value, high-volume claims, and because of the contrast between the value of the transaction and the high cost of litigation. Consumers need to have a fair redress system, including for cross-border transactions, which will allow any person, whether familiar or unfamiliar with dispute resolution, to use a simple online mechanism, fast, effective and possibly for no costs. They expect a consumer-friendly service and interface, as well as to be guided swiftly through an online system. A good example is the settlement process offered by eBay for consumers' complaints.

If the mechanism is complicated and if the redress system is an arbitration procedure with all the complications it may entail, the consumers may end up dropping the complaint and the redress. In this event, the redress system that merchants wanted to offer to consumers would serve no purpose. In addition, consumers may lose confidence in online transactions.

Mediation is best suited for such types of disputes. The consumer is unlikely to be assisted by a lawyer to plead his/her case or to make submissions. The consumer will express his/her position in his/her own words. He/she wants the dispute resolution provider to understand the problem and suggest a solution through a simple mechanism (whether automated or otherwise). The consumer expects neither an award nor to have to apply for enforcement of the decision. Therefore, for consumer disputes it is inconceivable to impose an arbitration procedure: the poles of the battlefield between businesses and consumers are entirely apart.

In a case where a consumer purchased software following which a dispute arose, and where the dispute resolution clause in the general conditions imposed on the consumer to submit disputes to the ICC, a state court decided that the ICC arbitration clause was unconscionable in consumer contracts and that the arbitration could not be imposed on the buyer. ${ }^{9}$

As a result, there seems to be confusion between the services to be put in place for consumer disputes. Arbitration is probably not the process desired for small-value, straightforward disputes requiring swift settlement, although it should remain open. If arbitration is the process to be used, there is no need to create a new arbitration process, as some of the contributors of the UNCITRAL ODR WG seemed to be suggesting. Arbitration institutions already exist and have procedures administered in accordance with their rules. However, if the proposal 
is to offer a centralized system proposing mediation and arbitration to consumers with the possibility to file their claims and conduct the procedure online, then indeed generic rules may be suggested for mediation procedures and for arbitration procedures. The latter may take inspiration from simplified procedures such as the expedited arbitration procedures or arbitration procedures for small claims offered by several arbitration institutions. A two-tiered procedure may also be offered, starting with mediation. If mediation and arbitration is the avenue to travel, the other issue that needs to be addressed is to know whether the centralized system will be an ODR provider handling consumer disputes under both types of mechanisms - mediation and arbitration - or if the centralized system will only be a clearing house that will be transferring the disputes to existing ODR providers who will apply both generic rules, for mediation and arbitration procedures. The latter system is what the European Union is suggesting to put in place, as will be mentioned below, although arbitration is not proposed. Another example is ICANN, which has rules for domain names disputes applied by ODR providers designated by ICANN.

This determination leads to the next clarification. If mediation is the redress mechanism to be used, do issues of choice of court, applicable law, place of arbitration and enforceable award need to be addressed?

\subsection{Fourth Clarification: Are Procedural Issues for Disputes Resolved through Mediation Similar to Those Resolved through Arbitration?}

Confusion also exists when the contributors and the actors discuss issues of choice of court, applicable law, place of arbitration and enforceable award. ${ }^{10}$ Either the debate is about mediation or about arbitration, in which case whether the arbitration procedure is conducted online or offline makes no difference: the choice of the dispute resolution mechanism, the applicable law, the place of arbitration and the enforceability of the award will be interpreted the same way whether the procedure is conducted online or offline. The only difference resides in the fact of conducting a procedure in an online environment using Web platforms that allows users to benefit - among other advantages - from swift communications and instantaneous access to information. If the debate is about mediation, there should be no debate over the place of arbitration, choice of court, choice of law and enforceable award.

The focal point must be the redress mechanism to be offered to unsatisfied consumers, whether through assisted negotiation, automated mechanism or something else. Issues in consumer disputes are more of facts rather than law. Decisions are not based on law, but on solutions that may be standard and adapted to typical problems.

Likewise, if the discussions are about mediation, the decision or solution provided to an unhappy consumer is not an award rendered by an arbitrator who

10 See in this regard, M. Philippe, 'Where Is Everyone Going With Online Dispute Resolution (ODR)', Revue de Droit des Affaires Internationales, No. 2, 2002, p. 167 at pp. 171-178, and also 'Now Where Do We Stand With Online Dispute Resolution (ODR)', Revue de Droit des Affaires Internationales, No. 6, 2010, p. 563 at pp. 571-575. 
heard the parties, deliberated and rendered a decision. The decision may not be binding on the consumer like an award. The consumer retains the right to submit a dispute to state courts, although this is not recommended considering the courts' workload and the constraints of court proceedings. The purpose of an ODR redress system is precisely to avoid overloading the courts with low-value, high-volume disputes and to stay away from lengthy and costly proceedings. Consumers usually do not travel this avenue, taking into account the complication state courts proceedings may represent and the fact that they may be unaware of the procedures to follow. Therefore, efforts should be concentrated on offering ODR user-friendly and fair redress mechanisms.

Mindful of the distinctions made in the first part of the article, the next part will address mainly some aspects of the discussions of the UNCITRAL ODR WG.

\section{Are Contributors and Actors on the Same Wavelength?}

UNCITRAL has been discussing cross-border e-commerce transactions since 2009. In 2010 it decided to create a working group entrusted with the drafting of a set of rules for a global ODR system to handle low-value, high-volume claims. ${ }^{11}$ The various reports of the working group available on the UNCITRAL website ${ }^{12}$ give the impression that the discussions of some contributors depart from the purpose of creating a simple redress system for low-value, high-volume disputes. Contributors and actors may sometimes not be on the same wavelength, which is understandable considering the multitude of their backgrounds and cultures. ${ }^{13}$ The purpose of the second part of this article is to consider whether some aspects of the discussions - without getting into details - of the UNCITRAL ODR WG may be confusing in light of the clarifications made in the first part (Section 2.1). It will then be interesting to see how the new European Union Regulation on ODR tackles the issues of a redress system for consumer disputes (Section 2.2).

\subsection{Discussions of the UNCITRAL ODR WG}

The issue of a normative instrument for ODR was raised a few times at the UNCITRAL meetings. The UNCITRAL Secretariat had concluded in 2003 that it was too early to engage in the preparation of any normative instrument and that it would be best to continue analysing the various experiments, gather information and prepare studies to enlighten further debate on how these issues might be addressed. ${ }^{14}$ In 2009 the United States recommended that the UNCITRAL Secre-

11 See the excellent summary of the issues at stake in C. Rule, V. Rogers \& L.F. Del Duca, 'Designing a Global Consumer Online Dispute Resolution (ODR) System for Cross-border Small Value - High Volume Claims - OAS Developments', Uniform Commercial Code Law Journal, Vol. 42, 2010, p. 221, <http://papers.ssrn.com/sol3/papers.cfm?abstract_id=1635463〉.

12 <www.uncitral.org/uncitral/en/commission/working_groups/3Online_Dispute_Resolution. html $>$

13 See on this subject D. Rainey, 'ODR and Culture', in Abdel Wahab et al., 2012, p. 197.

14 See Report A/CN.9/681/Add.2, p. 1, <www.uncitral.org/uncitral/en/commission/sessions/42nd. html>. 
tariat be asked to prepare a study on possible future work that UNCITRAL might engage on the subject of ODR in cross-border e-commerce transactions. ${ }^{15}$

Pursuant to that request, the UNCITRAL Secretariat organized a colloquium in March 2010 in cooperation with the Pace Law School Institute of International Commercial Law and the Penn State Dickinson School of Law, ${ }^{16}$ during which the evolution of e-commerce and the initiatives related to resolution of disputes originating from $\mathrm{B} 2 \mathrm{~B}$ and $\mathrm{B} 2 \mathrm{C}$ transactions were discussed. The views were that the traditional judicial mechanisms are not adapted to cross-border e-commerce disputes and that a global ODR system for low-value, high-volume B2B and B2C disputes is needed, which should 'not impose costs, delays and burdens that are disproportionate to the economic value at stake'. ${ }^{17}$ It seemed clear from the outset that the need for a system to be put in place was different from the classical arbitration system. Participants concluded that it may be timely to deal with the matter internationally and to design generic rules that, 'consistent with the approach adopted in UNCITRAL instruments (such as the Model law on Electronic Commerce), could apply in both business-to-business and business-toconsumer environments'. ${ }^{18}$ The author is not convinced that both environments should be handled in a similar way as will be discussed.

At the same session, the Commission agreed that a Working Group III should be established to undertake work in the field of ODR relating to cross-border e-commerce transactions. It was further indicated that the work of such a group would not overlap with Working Group II on arbitration and conciliation, as ODR raises separate issues '[...] particularly those associated with the need for rapid resolution of high-volume, low-value disputes arising primarily from transactions carried out by way of electronic communications [...]'. ${ }^{19}$ Therefore, and although the discussions concern the resolution of disputes, it seemed clear that ODR standards may be separate from the conciliation and arbitration standards. Undeniably, disputes originating from transactions through electronic communications involve issues at stake different from the issues of purely business transactions, which usually submit disputes to arbitration. Classical arbitration is not adapted to low-value, high-volume disputes. During the discussions it was also recommended that '[...] the consensus-based system should be friendly to consumers, cost-effective to business and fair to consumers, and be consistent with local consumer protection mandates. ${ }^{20}$ The emphasis was clearly put on the consumers.

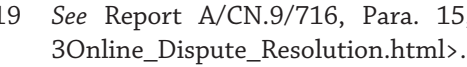

20 See details in Report A/CN.9/706, Para. 48, <www.uncitral.org/uncitral/en/commission/ sessions/43rd.html >; see also A/CN.9/769, Para. 18. 
At a subsequent session, ${ }^{21}$ it was further mentioned that the '[...] enforcement was less of an issue in cases dealt with through conciliation, which was in fact the majority of low value transaction cases'. This again demonstrates that reference was clearly made to consumer disputes, and it is interesting to note that conciliation was referred to as being the technique for resolving low-value transactions. Contributors were therefore aware of this important distinction.

The UNCITRAL ODR WG was entrusted with the drafting of generic rules for a global ODR system in low-value, high-volume, B2B and B2C cross-border disputes. Typically, the B2B referred to would be small-value disputes. The generic rules are normally meant to offer consumers a uniform set of rules to enable any consumer to understand what mechanisms can be used and learn about the rules of the game for resolving consumer disputes.

Like many actors, the author welcomed this project on ODR because its main purpose is to offer a standard and uniform system, easy to access and to implement by consumers from all over the world looking for a simple redress system. The author had suggested on a few occasions that standards and model rules be established to avoid striking differences between the services and to offer the users predictability; lists of criteria were also provided for the establishment of uniform rules and of standards to be applied by providers. ${ }^{22}$

When reading the reports of the UNCITRAL ODR WG, the reader is sometimes under the impression that the contributors are drafting a text similar on some aspects to the UNCITRAL Model Law or Model Rules on Arbitration. While consistency is recommended to remain in the same spirit of generic rules adapted to generic situations and to offer an instrument adapted to consumer disputes, the question is to know whether it is necessary to create a new instrument for business disputes, unless the question as to how these generic rules will be used is answered as raised above. Likewise, is there a need for creating an instrument for consumer disputes similar to the instrument for pure business disputes, not to speak about the complications related to consumer protection rules, which will not be discussed in this article ${ }^{23}$ A single instrument seemed to be created at one point for two different types of disputes despite the fact that it was clearly pointed out that '[...] ODR procedural rules might be different from arbitration rules [...]', ${ }^{24}$ and despite the reference clearly made to buyers who will be offered the choice to accept the procedural rules. ${ }^{25}$ The choice given to buyers means that the adoption of the ODR procedural rules may not have been negotiated between the parties prior to the transaction, and thus may not be binding upon them like any dispute resolution agreement negotiated and adopted, and which becomes binding upon the parties.

21 See Report A/CN.9/716, p. 17, <www.uncitral.org/uncitral/commission/working_groups/ 3Online_Dispute_Resolution.html>.

22 See in this regard, Philippe, 2002, pp. 183-188, and also Philippe, 2010, pp. 565-569.

23 See the interesting Report A/CN.9/706, <http://daccess-dds-ny.un.org/doc/UNDOC/GEN/ V10/531/00/PDF/V1053100.pdf?OpenElement>.

24 See Report A/CN.9/721, Para. 69, <www.uncitral.org/uncitral/commission/working_groups/ 3Online_Dispute_Resolution.html>. 
The reports of the UNCITRAL ODR WG reflect at some points a complicated process for simple, small-value, consumer disputes, or were referring to classical arbitration procedures. It seemed to depart occasionally from the initial purpose aimed at offering consumers redress at low cost or no cost and a simple procedure that does not require legal assistance. If the goal is to deal with low-value, highvolume consumer disputes, it is to be doubted that pure business disputes should be merged with consumer disputes and treated the same way.

Even though emphasis was put on the need for a redress system for consumer disputes, the discussions referred from time to time indistinctly to businesses and consumers, or to conciliation and arbitration. On other occasions, it was suggested that no mention of B2B, B2C or C2C nor of consumer and business be made, to avoid problems relating to definition of the parties, ${ }^{26}$ and that 'most consumers would choose to proceed by way of ODR rather than the costly and less attractive route of litigation in the courts'. ${ }^{27}$ This shows again that contributors were aware of the fact that consumers are a different species and so are the disputes involving them.

Further, the draft procedural rules as they currently stand are clearly defined in the preamble as being the UNCITRAL ODR rules '[...] intended for use in the context of cross-border, low-value, high-volume transactions conducted by means of electronic communication'. ${ }^{28}$ Hence, the rules for business disputes and consumer disputes cannot be the same. Business disputes usually of higher value than the consumer disputes involve businesses who may be familiar with arbitration as opposed to consumers, and who are not concerned by the ODR redress system designed for consumers. Dispute resolution institutions exist, as discussed above, and deal with pure B2B disputes. When reading the reports, the reader is sometimes under the impression that discussions, now and then, end up being the same as in any arbitration forum, although the issue here is supposed to be limited to low-value, high-volume disputes.

The hesitation on the form of the procedure is also reflected in the fact that contributors refer in the draft procedural rules to the issuing of a decision or an award, both words being still in brackets meaning that this issue remains to be determined. ${ }^{29}$ As discussed above, are low-value, high-volume claims supposed to be resolved through mediation or through arbitration?

The same remark goes for the discussion on the enforcement of arbitral decisions which only concern arbitration. ${ }^{30}$ Although arbitration may remain open for consumers if they agree to bring a claim to arbitration, it is unlikely that consumer disputes would be submitted to arbitration. Consumers are not expected

See Report A/CN.9/721, p. 7, <www.uncitral.org/uncitral/commission/working_groups/3Online _Dispute_Resolution.html $>$.

Id. p. 8.

See Report A/CN.9/WG.III/WP.123, Para. 11, <www.uncitral.org/uncitral/commission/working _groups/3Online_Dispute_Resolution.html $>$.

29 See Report A/CN.9/WG.III/WP.109, Para. 72, <www.uncitral.org/uncitral/commission/working _groups/3Online_Dispute_Resolution.html> and A/CN.9/762, Para. 26-28, <www.uncitral. org/ uncitral/commission/working_groups/3Online_Dispute_Resolution.html $>$. See Report A/CN.9/WG.III/WP.125, point V, p. 8. 
and will probably not go through a classical arbitration procedure for small-value claims, considering the costs and time it may involve. They are even less expected to go through the hurdle of enforcement of decisions. Incidentally, the statement that '[...] it was generally agreed that ODR arbitral decisions should be final and binding, with no appeals on the substance of the dispute [...]' may seem surprising, ${ }^{31}$ as the final and binding arbitral decision principle applies to arbitral decisions, whether the arbitration is conducted online or offline.

It is true that some underdeveloped and developing countries expressed the concern that decisions should be final and binding and enforceable, considering the lack of basic legal frameworks in their countries. Yet it is difficult to see how a simple redress system staying away from complicated procedures and enforcements at courts can reconcile with the need for such a purely arbitration system with enforceable arbitral decisions, not to speak about the fact that such dispute resolution services already exist and need not be included in the generic procedural rules. In the author's view, both needs and concerns cannot be addressed in the same instrument. The need for binding and enforceable decisions may be addressed by submitting, for instance, the consumer disputes to expedited arbitration procedures or arbitration procedures designed for small claims that several arbitral institutions offer. Also, as discussed above, the question on how potential generic rules for mediation and generic rules for arbitration will be used needs to be answered.

Finally, the work so far achieved by the UNCITRAL ODR WG is significant as it is important that uniform practices be put in place, although some issues remain to be defined and the work to be completed.

In addition to UNCITRAL, another project was achieved by another body with respect to a consumer redress system, although a process already existed in the year 2000 (the EEJ-Net ${ }^{32}$ ). The European Union adopted in 2013 a Regulation on ODR.

\subsection{The European Union Recent Regulation on ODR}

The Council of the European Union (hereinafter 'Council') adopted a directive on alternative dispute resolution (ADR) and a regulation on ODR (hereinafter 'Regulation'), which were published in the Official Journal of the European Union on 18 June $2013 .{ }^{33}$ A few salient points of the Regulation ${ }^{34}$ are interesting to note.

The new legislation on ADR and ODR are aimed at providing consumers and traders the possibility to solve their disputes out of court, in a fast, low-cost and simple way. Consumers will be able to submit any type of contractual disputes with traders, except disputes related to health and higher education, irrespective

31 See Report A/CN.9/716, Para. 99, <http://daccess-dds-ny.un.org/doc/UNDOC/GEN/ V11/801/48/PDF/V1180148.pdf?OpenElement>.

32 For further information, see <http://europa.eu/legislation_summaries/other/132043_en.htm>.

33 See <http://ec.europa.eu/consumers/redress_cons/adr_policy_work_en.htm>.

34 Regulation of the European Parliament and of the Council on online dispute resolution for consumer disputes: <http://eur-lex.europa.eu/LexUriServ/LexUriServ.do?uri=OJ:L:2013:165:0001: 0012:EN:PDF>. 
of the fact that the product or the service is purchased domestically or across borders, provided it is purchased online.

A European ODR platform (hereinafter 'Platform') for all Member States will be set up by the end of 2015 to allow for online settlement of disputes. It will offer a free-of-charge electronic case management tool. Online traders established within the Union will have to provide on their website a link to the Platform so as to ensure consumer awareness about the existence of such a service. The Platform will be a single point of entry for consumers and traders seeking out-of-court resolution of disputes covered by this Regulation. It should build on existing ADR entities in the Member States. ADR entities to which a complaint is transmitted through the Platform will apply their own procedural rules, but this Regulation establishes common rules applicable to all.

The Regulation lists the services that the Platform will offer. ${ }^{35}$ It is interesting to see that similar services to those suggested a decade ago by the author will be adopted. ${ }^{36}$

The Council considered that '[...] consumers are key players in the internal market and should therefore be at its heart [...]', and that '[...] consumers and traders should feel confident in carrying out transactions online so it is essential to dismantle existing barriers and to boost consumer confidence. ${ }^{37}$ These statements summarize the reason for putting in place a system that enhances online transactions by offering a viable settlement mechanism. The Regulation clearly states that ODR is not intended to replace court procedures, nor deprive consumers or traders from seeking redress before state courts.

This project probably benefited from the experience gained by the various actors with building various platforms and sharing their experiences in the ODR field during the yearly meetings. ODR actors look forward to this Platform and to the success of this service, which will hopefully inspire other initiatives worldwide.

\section{Conclusion}

To conclude, clarifying certain issues was indispensable for trying to speak the same language. (1) Online arbitration may be understood as a procedure exclusively conducted online, for instance in consumer disputes and domain names disputes, as opposed to arbitration procedures in business disputes using information technology as a facility; however, irrespective of whether the procedure is conducted partially or exclusively online, it may be considered online arbitration whenever a Web-based programme is utilized for a given service, and this is ODR. (2) Settlement of disputes opposing B2B is different from settling disputes in $\mathrm{B} 2 \mathrm{C}$, as the first type of disputes may be settled through an arbitration procedure, whereas the second need not go through the complications of an arbitration procedure. (3) Therefore, the mechanism best adapted to consumer disputes is medi-

36 Philippe, 2002, pp. 183-188, and also Philippe, 2010, pp. 565-569. 
ation as opposed to arbitration, although arbitration should remain a possible mechanism. (4) The direct consequence of a mediation procedure is the fact that the choice of court, applicable law, place of arbitration and enforceable award are non-issues.

Bearing in mind the clarifications made, this article raised some issues related to the discussions of the UNCITRAL ODR WG for consumer redress where contributors seemed not to be on the same wavelength on certain aspects. In the author's view, a simple redress system and an arbitration system leading to enforceable arbitral decisions cannot be addressed in the same instrument. The need for binding and enforceable decisions may be addressed by submitting consumer disputes to expedited arbitration procedures or arbitration procedures designed for small claims. If the proposal is to offer a centralized system proposing mediation and arbitration to consumers, then two sets of generic rules may be suggested for the mediation and the arbitration procedures, or a two-tiered procedure. If this is the proposal, will the centralized system be an ODR provider handling consumer disputes under both types of mechanisms, or will it only be a clearing house transferring the disputes to existing ODR providers who will apply the generic rules?

Finally, it was interesting to note that the European Union adopted a Regulation on ODR for consumer disputes in 2013 and will put in place a European ODR Platform for all Member States.

A redress system for consumer disputes has been discussed for a decade and is clearly needed; the various initiatives undertaken to respond to this need demonstrate that the ODR field continues to be built and new services to be offered, which will contribute to the development of online transactions. 